\title{
Negative Real Interest Rate and Housing Bubble Implosion - An Empirical Study in Hong Kong
}

\author{
by \\ Chung Yim Yiu \\ Department of Real Estate and Construction, The University of Hong Kong
}

15 July 2009

*Corresponding author:

C.Y. Yiu

Assistant Professor

Department of Real Estate and Construction

The University of Hong Kong

Pokfulam

Hong Kong

Tel: (852) 2857-8629

Fax: (852) 2559-9457

E-mail address: ecyyiu@hku.hk 


\title{
Negative Real Interest Rate and Housing Bubble - an Empirical Study in Hong Kong
}

\begin{abstract}
This paper tests empirically the relationship between real interest rate and housing return in Hong Kong. The time series date from the first quarter of 1984 to the first quarter of 2009. Employing multiple regression analysis with autoregressive and lagged independent variables, it shows that housing bubble implosions could be largely explained by the negative real interest rate. Furthermore, it shows an asymmetric effect of real interest rate on housing return. It can be a good predictor for housing bubbles in the future.
\end{abstract}

Keywords: Real Interest Rate, Housing Bubble

\section{INTRODUCTION}

The negative relationship between real interest rate and housing return has long been established theoretically since Fisher (1930) and has been confirmed empirically by Gibson (1972), Schwab (1983), Harris (1989), and Hui and Yiu (2003), etc. However, there have been very few studies on negative real interest rate, let alone its effects on housing bubble implosion. The reason is probably because negative real interest rate is very rare in any parts of the world at any time of the history. Theoretically, negative real interest rate is considered abnormal, as it renders Gordon Growth Model and Campbell and Shiller's (1988) Dividend-Ratio Model inoperable. In general, monetary policy is to smooth economic fluctuations, thus it often results in a general converging trend between nominal interest rate and inflation rate. However, under the currency board (linked exchange rate at US\$1 = HK\$7.8) system implemented in Hong Kong since October 1983, nominal interest rates in Hong Kong are exogenously determined by the US interest rates ${ }^{1}$. As a consequence, unlike most of the other economies, negative real interest rates have been commonly

1 “... and risk premium required by investors to hold Hong Kong dollar assets.” (HKMA, 2006) 
found in Hong Kong in the past 25 years ${ }^{2}$. Probably it is the only city which has such a high proportion of negative real interest rate period, and encountered two large-scale housing bubble implosions within a 10-year horizon. It enables the first empirical study on the impact of negative interest rate on housing return.

Yet, if that is the case, then this study would be very limited in its implications, and of no generalized insights for global markets. However, with the prevalence of fiat money and bank money in recent decades, together with the globalization of funds and shadow banking system ${ }^{3}$, negative real interest rate has no longer been an abnormal situation, and it is expected to be more common in the future. For example, the recent sub-prime crisis is also found to be coincided with a period of negative real interest rate in the US (Yiu et al., 2009). Unfortunately, there are extremely few studies on the impacts of negative real interest rate on asset pricing, and the international markets have little experience on this phenomenon.

This paper thus attempts to study macro-economic variables, especially negative real interest rate, which are believed to be factors affecting private housing price change, in Hong Kong from the first quarter of 1984 (when the currency board system has been implemented for a quarter) to the first quarter of 2009, a 101-quarter long data series.

The paper is arranged into six sections. The next section conducts a literature review on negative real interest rate and asset pricing. Then the methodology and data are discussed in Section 3. Sections 4 and 5 present the empirical models and results, respectively. A conclusion is provided in Section 6.

\section{LITERATURE REVIEW}

The importance of real interest rate on asset pricing has long been recognized, as it is the price of credit. Negative real interest rate is commonly regarded as abnormal because when the price of credit is negative, rational creditors should not lend their money to debtors and rational people should retrieve their savings. Thus, originally the market mechanisms should be able to rectify the situation by increasing the interest rate to attract back the savings, and decreasing the inflation rate as spending is restricted by the lack of credit.

\footnotetext{
239 out of 101 quarters of negative real interest rate from 1984Q1 to 2009Q1, i.e about 39\%.

${ }^{3}$ To be detailed in the Literature Review section.
} 
However, there are at least three new changes on money and credit expansion in the recent decades that make these market checking mechanisms almost fail. First, huge global fund flows are swiftly sweeping across cities. Second, there are now fiat money (money supply not restricted by commodities) and bank money (credit supply unchecked by deposits) artificially created by central banks and merchant banks respectively. Third, a new "shadow banking system" has been established to package and distribute the money and credit created, which is not governed by the Basel II Accord either. These three changes are well recognized in literatures, especially after the sub-prime crisis, as elaborated below.

With the forces of financial globalization and the swift movement of huge global funds, Smick (2008) contended that asset price can be totally out of the local governor's control. Before 1971, money expansion was restricted by gold reserves or a fixed exchange rate. However, along with the abolition of the gold standards and the Bretton Woods system, money become fiat money, and its expansion is uncontrollable (Cooper, 2008; Woods, 2009). Similarly, credit expansion was originally checked by savings and total deposits, but since the prevalence of bank money, such as credit card and electronic money, credit can now be created from vacuum. The risk controls on banking industry, such as the Basel II Accord, is unleashed (Pettifor, 2006).

When excessive money is chasing scarce resources, the result is a general increase of price. Nowadays, more and more natural resources are at the verge of extinction: the current demand of fossil fuels, precious metals, timbers, food, etc. are unprecedented. The heightened aspiration of living standards and the change of living style in recent decades further exacerbate the scarcity of natural resources. It has become more and more inelastic to increase the supply of assets and commodities, which Glaeson et al. (2008) and Goodman and Thibadeau (2008) considered it a reason of the housing bubble.

Exchange rate between currencies is originally a checking force on trade surplus or deficit, which should be reflected on its interest rate and inflation rate of an economy. However, almost all of the trade surpluses earned by other countries from the US consumptions flows back to the US by buying the Treasury Bonds of the US Government. The exchange rate does not actually reflect the trade surplus or deficit. Furthermore, many economies heavily rely on exports for their GDP growth, any 
increases in their currencies would severely hinder their export markets, and thus many governments do not hesitate to intervene the strength of their currencies.

These unchecked money and credit expansions have already resulted in several crises or even bubble implosions, but some of the potential recessions were repeatedly prevented and failed institutions were repeatedly bailed out by governments, borrowers have become more and more risk-seeking and dare to demand an even greater stock of debt. Lenders would also be more aggressive and risk-preferred. Osborne (2001) even found it becomes a globalized moral hazard. Zandi (2009) found that more and more "predatory loans” (granting loans without regard to the borrowers' ability to make timely payments) were granted, including sub-prime mortgages, in the US, which is found to be one of the fundamental causes of the crisis. For example, in 2005, "almost half of all mortgage-linked bonds in America were based on sub-prime loans.” (Tett, 2009, p.95)

If the level of risk exposure can be accurately assessed, the increase in risk premium would counterbalance the reduction in interest rate and the increase in inflation rate. Unfortunately, risk assessment has been largely distorted by the Shadow Banking System. With the invention of asset-backed securities (ABS and MBS), credit derivatives (CDO and CDS), and their indices (ABX, TABX, CMBX, $\mathrm{CDX}, \mathrm{LCDX})^{4}$, default risk of mortgages and loans is thought to be transferrable or insurable, suddenly it reduces sharply credit risk premium in the markets. However, the actual risk level of the various tranches of the pooled loans in the derivative is not easily comprehensible, and credit rating becomes the sole indicator for the risk exposed. But even the credit rating agencies have difficulties in assessing the risk level of these derivatives, because of the lack of past record of a national-wide credit default, as raised in Tett (2009). Selling these derivatives through SIVs (Structured Investment Vehicles) can further avoid the capital requirements set by the Basel II Accord and regulations on banking industry. Without realizing the actual risk exposure, risk premium was seriously underestimated, which in turn would further reduce interest rate but increase inflation.

The unchecked credit expansion, unlimited asset demand growth, and the underestimation of risk strengthen the expectation of future income growth. New technologies and innovations of investment tools made people believe that 
unprecedented and unlimited future income growth was promising. The world is so flat that manufacturing and operating costs seem to be ever decreasing. Negative real interest rate is thus no longer abnormal, but its real impacts were not realized until the sub-prime crisis in 2008.

\section{METHODOLOGY AND DATA}

In this study, a time series regression analysis is applied to investigate the impacts of negative real interest rate on housing price change (i.e. quarterly housing investment return), with two other key macro-economic variables being included. Table 1 defines the variables and shows their summary statistics and stationarity test results:

Table 1 Definitions, Summary Statistics and Stationarity of the Data Series,

$$
\text { 1984Q1 - 2009Q1 }
$$

\begin{tabular}{|c|c|c|}
\hline \multicolumn{3}{|c|}{ Panel A: Descriptions and Units of Measure } \\
\hline Symbol & Descriptions & $\begin{array}{l}\text { Units of } \\
\text { Measure }\end{array}$ \\
\hline$d \log (H P I)$ & $\begin{array}{l}\text { Change of housing price (i.e. investment return), } \\
\text { measured by the quarterly change of the Rating and } \\
\text { Valuation Department's (RVD, 2009) Housing Price } \\
\text { Index (all classes), which is } 100 \text { in } 1999 .\end{array}$ & $\%$ \\
\hline$d \log (G D P)$ & $\begin{array}{l}\text { Change of real Gross Domestic Products (GDP), } \\
\text { measured by the quarterly change of the Census and } \\
\text { Statistics Department's (CSD, 2009) Constant GDP } \\
\text { series, which is in Hong Kong million dollars at the } \\
2007 \text { price levels and is seasonally adjusted by X-12. }\end{array}$ & $\%$ \\
\hline$d(U N E)$ & $\begin{array}{l}\text { Change of unemployment rate, measured by the } \\
\text { quarterly change of the Census and Statistics } \\
\text { Department's (CSD, 2009) seasonally adjusted } \\
\text { unemployment rate series. }\end{array}$ & $\%$ \\
\hline
\end{tabular}

${ }^{4}$ ABS = Asset-backed Securities, MBS = Mortgage-backed Securities, CDO = Collateralized Debt Obligations, $\mathrm{CDS}=$ Credit Default Swaps, $\mathrm{X}=$ Index . 
IBOR Inter-bank offer rate p.a. - 6 months, end of period \% figures (a proxy for the nominal interest rate p.a.), directly obtained from HKMA (2009)

$d(C P I) \quad$ Change of consumer price index - series A (a proxy \% for the inflation rate), measured by the quarterly change of the Census and Statistics Department's (CSD, 2009) year-to-year change of the CPI-A series.

Series A records the general price level of all nonluxury goods.

$d(R I R) \quad$ Change of real interest rate, measured by the quarterly \% change of $R I R=I B O R-d(C P I)$

\section{Panel B: Summary Statistics}

\begin{tabular}{ccccc} 
& Minimum & Maximum & Mean & $\begin{array}{c}\text { Standard } \\
\text { Deviation }\end{array}$ \\
\hline$d \log (H P I)$ & -18.55 & 17.47 & 1.8353 & 6.07 \\
$d \log (G D P)$ & -4.08 & 6.82 & 1.0696 & 1.92 \\
$d($ UNE $)$ & -0.73 & 1.07 & 0.0137 & 0.39 \\
$I B O R$ & 0.19 & 13.60 & 5.4356 & 2.80 \\
$d(C P I)$ & -5.87 & 12.37 & 4.1790 & 4.84 \\
$d(R I R)$ & -2.76 & 4.38 & 0.0069 & 1.30
\end{tabular}

\section{Panel C: Stationarity Tests (by Augmented Dickey-Fuller Unit Root Test)}

\begin{tabular}{cccc} 
Level & t-Statistic & First-difference & t-Statistic \\
\hline $\log (H P I)$ & -2.25 & $d \log (H P I)$ & $-4.80^{*}$ \\
$\log (G D P)$ & -1.43 & $d \log (G D P)$ & $-7.54^{*}$ \\
$(U N E)$ & -1.73 & $d(U N E)$ & $-4.95^{*}$ \\
$(R I R)$ & -1.51 & $d(R I R)$ & $-8.91^{*}$ \\
\hline
\end{tabular}

Legends:

$d$ : first-difference

log: natural logarithm

* statistically significant at the $1 \%$ level

Quarterly housing investment return, $d \log (H P I)$, in percentage can be calculated from RVD’s (2009) housing price index (all classes), which represents the general price level of private housing markets of all classes (sizes) of housing units in 
Hong Kong. GDP series is the quarterly expenditure-based Gross Domestic Products, obtained from CSD (2009). It represents the overall change of the economy of the city and is regarded as one of the market fundamentals affecting the demand for private housing. It is seasonally adjusted by $\mathrm{X}-12$. UNE is the rate of unemployment published by the government (CSD, 2009). It affects people's risk assessment in acquiring long term mortgages. Real interest rate $(R I R)$ is calculated by subtracting inflation rate $(d(C P I))$ by nominal interest rate $(I B O R)$. IBOR is the inter-bank offer rate p.a. in percentage which represents the nominal interest rate of the market. CPI is the consumer price index and series $A$ is used to measure the general price level of all non-luxury items in the market. Year-to-year change of CPI in percentage is a common proxy for inflation of the city.

The series are tested for their stationarity, with the results of the ADF tests shown in Panel $\mathrm{C}$ of Table 1. It shows that all the variables are non-stationary in level terms, but they are stationary in their first differenced terms. Therefore, the first differenced time series are exploited in the analysis to avoid spurious results. In taking first difference, if the variables are in percentage, then a simple first difference is taken, while if the variables are in terms of value, then first difference of the natural logarithm is used. It results in an interpretable set of variables, in terms of the change of growth rate.

Before discussing the empirical results, the following figures provide some casual observations of housing price and real interest rate in Hong Kong. Figure 1 shows the Housing Price Index (HPI - All Classes) of Hong Kong from 1984Q1 to 2009Q2, where it shows two bubble bursts, one in 1997 (the Asian Financial Crisis) and another in 2008 (the Global Financial Tsunami). Hong Kong is probably the only city encountered two bubble implosions of such a magnitude within a 10-year period. The index increased from 17 to 170 (1,000\% increase) from 1984 to 1997 (an upward price trend for 14-year), and then dropped to 60 (99\% decrease) from 1997 to 2003. It climbed up again to 126 (110\% increase) from 2003 to 2008 (an upward price trend for 6-year), when the financial tsunami came. Further price decrease is expected in the coming quarters. 


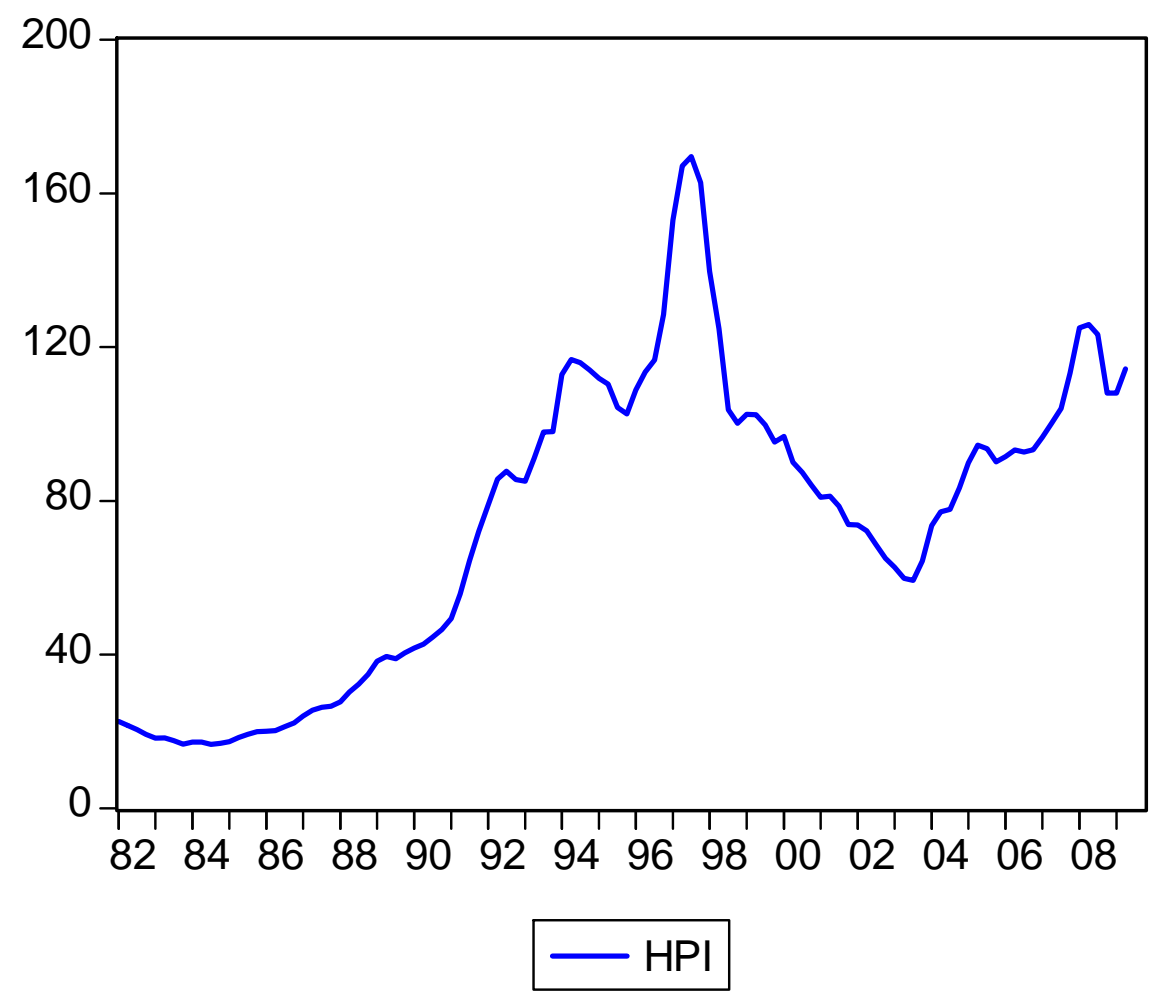

Figure 1 Housing Price Index (All Classes) in Hong Kong (1984Q1 - 2009Q2)

Source: Rating and Valuation (RVD) Department, Hong Kong SAR, http://www.rvd.gov.hk/en/publications/pro-review.htm

Figure 2 shows the trend of the real interest rate, calculated by subtracting the inflation rate from the Hong Kong inter-bank offer rate (6-month). It shows two periods of negative real interest rate, in 1988-1996 and 2008-2009. The ending of these two periods of negative real interest rate coincided with the two housing price bubble bursts in Hong Kong. 


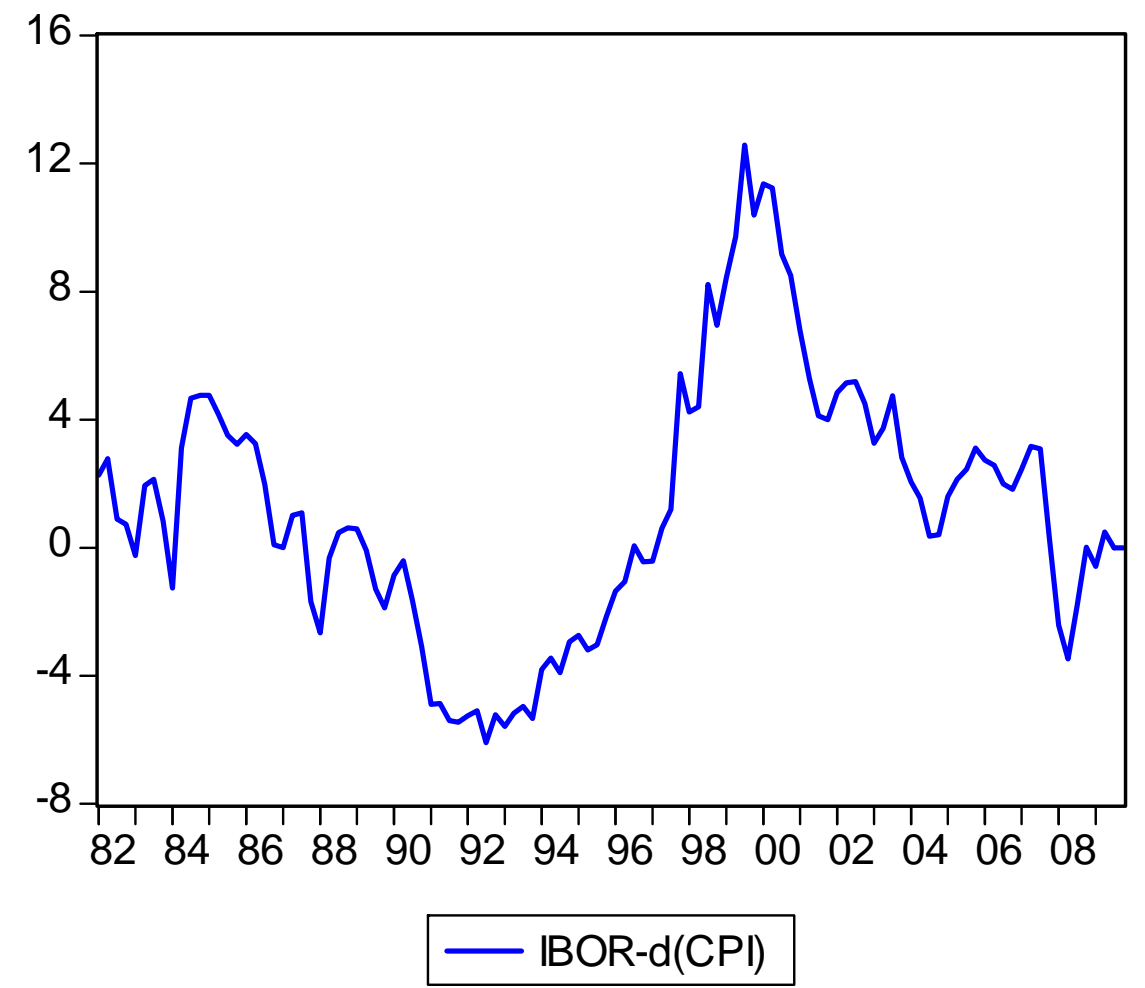

Figure 2 Real Interest Rate in Hong Kong (1984Q1 - 2009Q2)

Source: CPI from Census and Statistics (CSD) Department, Hong Kong SAR, http://www.censtatd.gov.hk/hong_kong_statistics/statistical_tables/index.jsp; IBOR from Hong Kong $\begin{array}{llll}\text { Monetary } & \text { Authority Hong }\end{array}$ http://www.info.gov.hk/hkma/eng/statistics/msb/attach/T060301.xls

Figure 3 is a scatter plot between the housing price change and the one-quarter lagging real interest rate. It shows a strong negative relationship between the two, as usually found in previous studies. However, very few studies explore the asymmetric effects of real interest rate (negative and positive rate) on housing price change. 


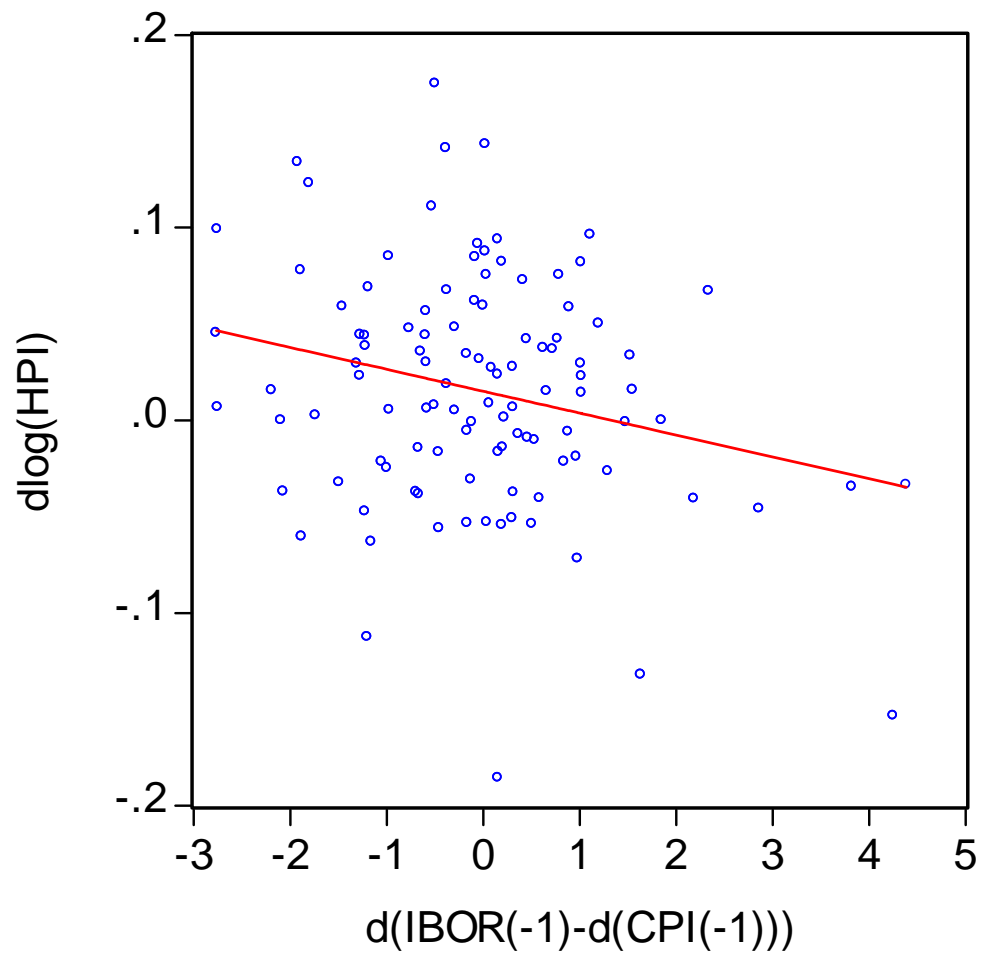

Figure 3 Scatterplot between Housing Price Change and Real Interest Rate in Hong Kong (1984Q1 - 2009Q2)

\section{EMPIRICAL MODELS}

Specifically, two empirical models are studied to examine the impacts of negative interest rate on housing price change. First-order autoregressive AR(1) term is exploited because significant $1^{\text {st }}$-order autoregression is identified by the correlogram. Furthermore, an one-quarter lag of $d(R I R)$ is found to be of the highest correlation with the dependent variables, which is probably because the dissemination of the information to the market takes time. Model 1 is a simple multiple regression of the three independent variables as shown in Equation (1):

$\left\{\begin{aligned} d \log \left(H P I_{t}\right) & =\alpha_{1}+\alpha_{2} d \log \left(G D P_{t}\right)+\alpha_{3} d\left(U N E_{t}\right)+\beta_{1} d\left(R I R_{t-1}\right)+\varepsilon_{t} \\ \varepsilon_{t} & =\rho \varepsilon_{t-1}+\mu_{t}\end{aligned}\right.$

where

$d \quad$ is a first differencing operator;

$\log \quad$ natural logarithm;

$\alpha_{k}$ and $\beta_{k} \quad$ are the coefficients to be estimated;

$\varepsilon_{t}$ and $\mu_{t} \quad$ are the stochastic terms; and 
Model 2 sub-divides the real interest rate variable into two regimes, namely positive and negative real interest rate ${ }^{5}$, as shown in Equation (2):

$$
\left\{\begin{aligned}
d \log \left(H P I_{t}\right) & =\alpha_{1}^{\prime}+\alpha_{2}^{\prime} d \log \left(G D P_{t}\right)+\alpha_{3}^{\prime} d\left(U N E_{t}\right)+\beta_{1}^{\prime} d\left(R I R_{t-1}^{+}\right)+\beta_{2}^{\prime} d\left(R I R_{t-1}^{-}\right)+\varepsilon_{t}^{\prime} \\
\varepsilon_{t}^{\prime} & =\rho \varepsilon_{t-1}^{\prime}+\mu_{t}^{\prime}
\end{aligned}\right.
$$

Model 1 tests the general effects of the three macro-economic factors, including the change of real interest rate; whereas Model 2 further investigates the effects of the change of real interest rate when it is positive or negative. It can study the asymmetric effects of real interest rate, and shed light on the relationship between negative real interest rate and housing price bubble implosions.

\section{RESULTS}

Table 2 shows the results of Model 1 and 2. First of all, the explanatory powers (50\%) are reasonably high in time series study of this kind. Second, the autoregressive characteristic of private housing price change is strong and significant ( $\rho=0.58$ ). All the signs of the coefficients are as expected, but the effect of economic growth (proxied by GDP) is not statistically significant, though positive. On the contrary, unemployment rate is found to exert a significant and negative effect on housing price change. One percent change of unemployment rate can produce about $4.5 \%$ change of housing price in the opposite direction. It is significant at the $1 \%$ level in both Models 1 and 2. Furthermore, real interest rate is found to impose a significant and negative impact on housing price change, as found in Model 1. It agrees in general with the theory of interest. However, if the effect of real interest rate is segregated into two regimes, namely positive and negative real interest rate, as shown in Model 2, the negative impact on housing price change from real interest rate change when the real interest rate is negative is almost double the magnitude of that when it is positive. One percent change in the real interest rate, when it is negative, produces $1.2 \%$ change in housing price change, in the opposite direction; but just $0.6 \%$ change when it is positive. Moreover, it is statistically significant at the $5 \%$

\footnotetext{
${ }^{5}$ More specifically, the positive and negative sign of the RIR is referred to the time at $t-2$, because $d\left(R I R_{t-1}\right)$ refers to $R I R_{t-1}-R I R_{t-2}$.
} 
level only when the real interest rate is negative. It confirms the hypothesis that the impact of real interest rate on housing price change is asymmetric, with a much stronger effect from the negative real interest rate.

Table 2 Regression Results on Models 1 and 2, 1984Q1 - 2009Q1

\begin{tabular}{|c|c|c|c|c|}
\hline \multirow{2}{*}{$\begin{array}{l}\text { Independent Variables } \\
\text { Constant }\end{array}$} & \multicolumn{2}{|c|}{$\begin{array}{c}\text { Model } 1 \\
\text { Coefficients }\end{array}$} & \multicolumn{2}{|c|}{$\begin{array}{c}\text { Model } 2 \\
\text { Coefficients }\end{array}$} \\
\hline & 1.9529 & $* * *$ & 2.0617 & $* * *$ \\
\hline$d \log \left(G D P_{t}\right)$ & 0.0752 & & 0.0359 & \\
\hline$d\left(U N E_{t}\right)$ & -4.5435 & $*$ & -4.8656 & $*$ \\
\hline$d\left(R I R_{t-1}\right)$ & -0.8240 & $* *$ & & - \\
\hline$d\left(R I R_{t-1}^{+}\right)$ & & & -0.6399 & \\
\hline$d\left(R I R_{t-1}^{-}\right)$ & & & -1.2255 & $* *$ \\
\hline$A R(1)$ & 0.5757 & $*$ & & \\
\hline Dependent Variable & \multicolumn{4}{|c|}{$d \log \left(H P I_{t}\right)$} \\
\hline Adjusted $R^{2}$ & 0.50 & & 0.49 & \\
\hline \multirow[t]{3}{*}{ DW statistic } & 1.92 & & 1.89 & \\
\hline & \multicolumn{4}{|c|}{ (White Heteroskedasticity-Consistent } \\
\hline & \multicolumn{4}{|c|}{ Standard Errors \& Covariance) } \\
\hline No. of Observations & \multicolumn{4}{|c|}{99 (1984Q3 - 2009Q1) } \\
\hline
\end{tabular}

$*, * *, * * *$ refer to statistical significance at the $1 \%, 5 \%$ and $10 \%$ level, respectively

Figure 4 charts together the percentage change of real interest rate and housing price in Hong Kong. Referring together with Figures 1 and 2 for the housing bubble implosions in 1998 and 2008, as well as the negative real interest rate period in 19881996 and 2008-2009, it shows clearly that the bubble burst in 1998 was caused by the several sharp rises $(+4 \%)$ in real interest rate after a long period of negative real interest rate. Similarly, the second bubble burst in 2008 was also triggered by a strong rise $(+2 \%)$ in real interest rate when it was negative. 


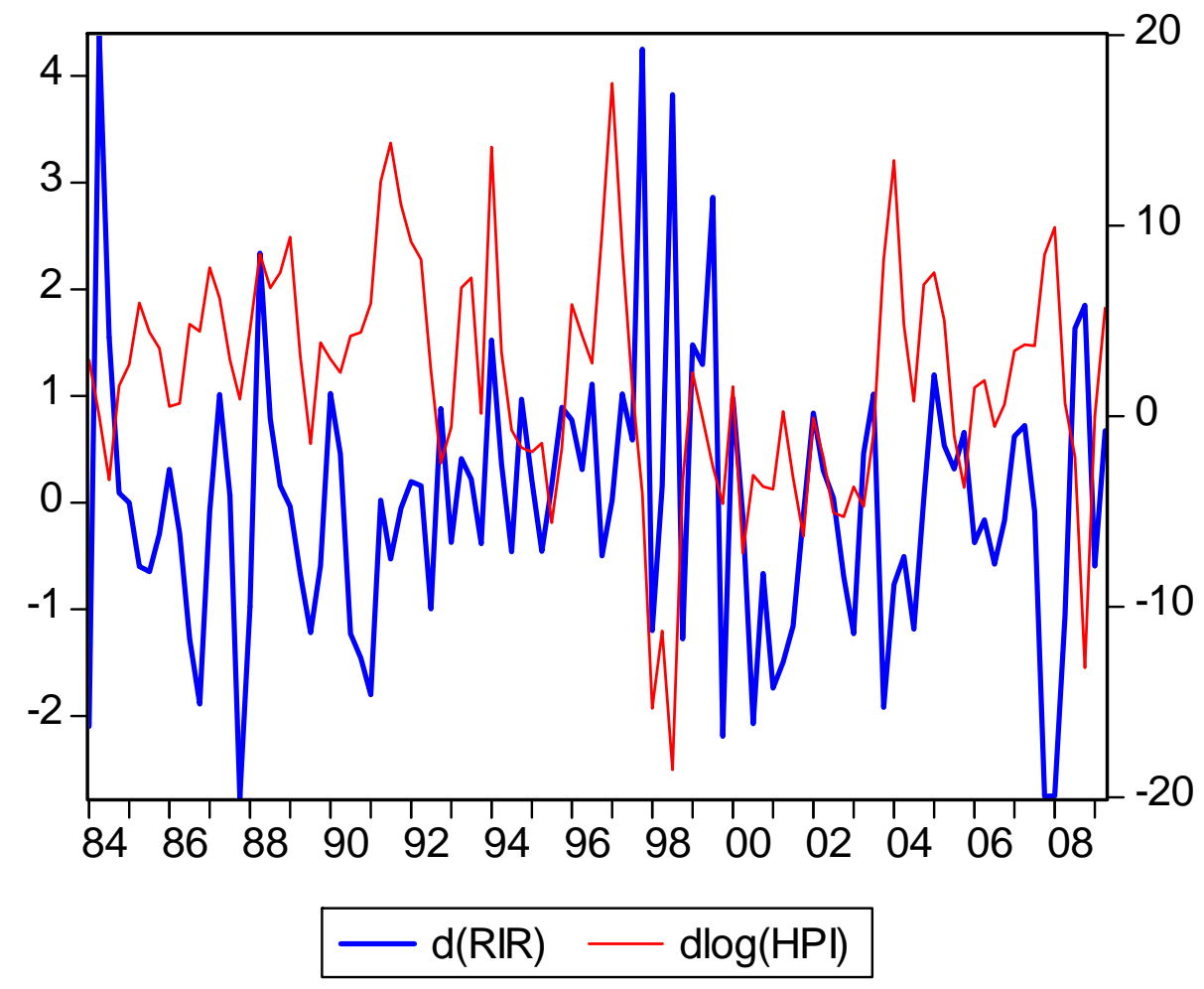

Figure 4 Percentage Change of Real Interest Rate (left axis) and Housing Price (right axis) in Hong Kong (1984Q1 - 2009Q2)

\section{CONCLUSIONS}

The impact of real interest rate on housing price change has long been recognized, yet the asymmetry of effect from negative and positive real interest rate has not yet been explored. It is probably because negative real interest rate was rare in the past; and was regarded as abnormal. However, with the recent financial institutional changes, negative real interest rate is more commonly found worldwide. For example, Zandi (2009, p.88) pointed out that "the global real rate went negative in 2002, and it did not turn positive again until well into 2006.” Unfortunately, there have been very few studies on negative real interest rate. This paper empirically tests the asymmetric impact of real interest rate on private housing price change in Hong Kong, from 1984Q1 to 2009Q1. The reason why the place and the period are chosen is because of the currency board arrangement adopted in Hong Kong since late 1983, which renders the change of real interest rate in Hong Kong almost totally exogenous. It provides one of the best data sources for the study of negative real interest rate. 
There are two housing bubble bursts in the past decade, and they are found to be coincided with the two negative real interest rate periods.

The empirical study employs two autoregressive and lagging regression models, one on the general effect of real interest rate and the other on the asymmetric effect of positive and negative real interest rate. The results show that the private housing price change is negatively related to the unemployment rate, and real interest rate. However, the negative impact from real interest rate is almost double when the real interest rate is negative. It confirms the hypothesis of the asymmetric effect of real interest rate, and it also explains why housing bubbles in Hong Kong burst. Further study is conducted to incorporate explicit risk premium and expected income growth.

The findings have important implications on government housing and monetary policies. The currency board system renders the real interest rate exogenous, and asset bubbles may become one of the consequences. It deserves further research on the market dynamics of asset price when real interest rate is negative.

\section{REFERENCES}

Campbell, J.Y. and Shiller, R.J. (1988) The Dividend-Price Ratio and Expectations of Future Dividends and Discount Factors, Review of Financial Studies, 1, 195228.

Copper, G. (2008) The Origin of Financial Crises, Vintage, New York, US.

CSD (2009) Hong Kong Statistics - Index of Statistical Tables at http://www.censtatd.gov.hk/hong_kong_statistics/statistical_tables/index.jsp, Census and Statistics (CSD) Department, Hong Kong SAR Government, Hong Kong, retrieved on 15 July 2009.

Fisher, I. (1930) The Theory of Interest, Macmillan, New York, US.

Gibson, W.E. (1972) Interest Rates and Inflationary Expectations: New Evidence, The American Economic Review, 62(5), 854-865.

Glaesen, E.L., Gyourko, J. and Saiz, A. (2008) Housing Supply and Housing Bubbles, Journal of Urban Economics, 64(2), 198-217. 
Goodman, A.C. and Thibodeau, T.G. (2008) Where are the Speculative Bubbles in US Housing Markets?, Journal of Housing Economics, 17, 117-137.

Harris, J. (1989) The Effect of Real Rate of Interest on Housing Prices, Journal of Real Estate Finance and Economics, 2(1), 47-60.

HKMA (2009) Monthly Statistics Bulletin - Inter-bank Offer Rates, at http://www.info.gov.hk/hkma/eng/statistics/msb/attach/T060301.xls, Hong Kong Monetary Authority (HKMA), Hong Kong, retrieved on 15 July 2009.

Hui, E.C.M. and Yiu, C.Y. (2003) Market Dynamics of Private Residential Real Estate Price - An Empirical Test in Hong Kong, Journal of Financial Management of Property and Construction, 8(3), Dec., 155-165.

Osborne, E. (2001) Financial Crashes in a Globalization Era, The Independent Review, 6(2), 165-184.

Pettifor, A. (2006) The Coming First World Debt Crisis, Palgrave Macmillan, New York, US.

RVD (2009) Property Review at http://www.rvd.gov.hk/en/publications/proreview.htm, Rating and Valuation (RVD) Department, Hong Kong SAR Government, Hong Kong, retrieved on 15 July 2009.

Schwab, R. (1983) Real and Nominal Interest Rates and The Demand for Housing, Journal of Urban Economics, 13, 181-195.

Smick, D.M. (2008) The World is Curved: Hidden Dangers to the Global Economy, Portfolio, US.

Tett, G. (2009) Fool's Gold: How the Bold Dream of a Small Tribe at J.P. Morgan was Corrupted by Wall Street Greed and Unleashed a Catastrophe, Free Press, New York, US.

Woods, T.E. Jr. (2009) Meltdown: A Free-Market Look at Why the Stock Market Collapsed, the Economy Tanked, and Government Bailouts will Make Things Worse, Regnery Publishing, Inc., Washington, D.C., US.

Yiu, C.Y., Xu, S.Y.S. and Cao, C.Y.J. (2009) Haven’t Learned from the Past? - A Common Symptom of Asset Price Bubble Implosions, ERES Conference, 26 May, Stockholm, Sweden. Also available at http://ssrn.com/abstract=1411587.

Zandi, M. (2009) Financial Shock: A $360^{\circ}$ Look at the Sub-prime Mortgage Implosion, and How to Avoid the Next Financial Crisis, Pearson Ed., New Jersey, US. 